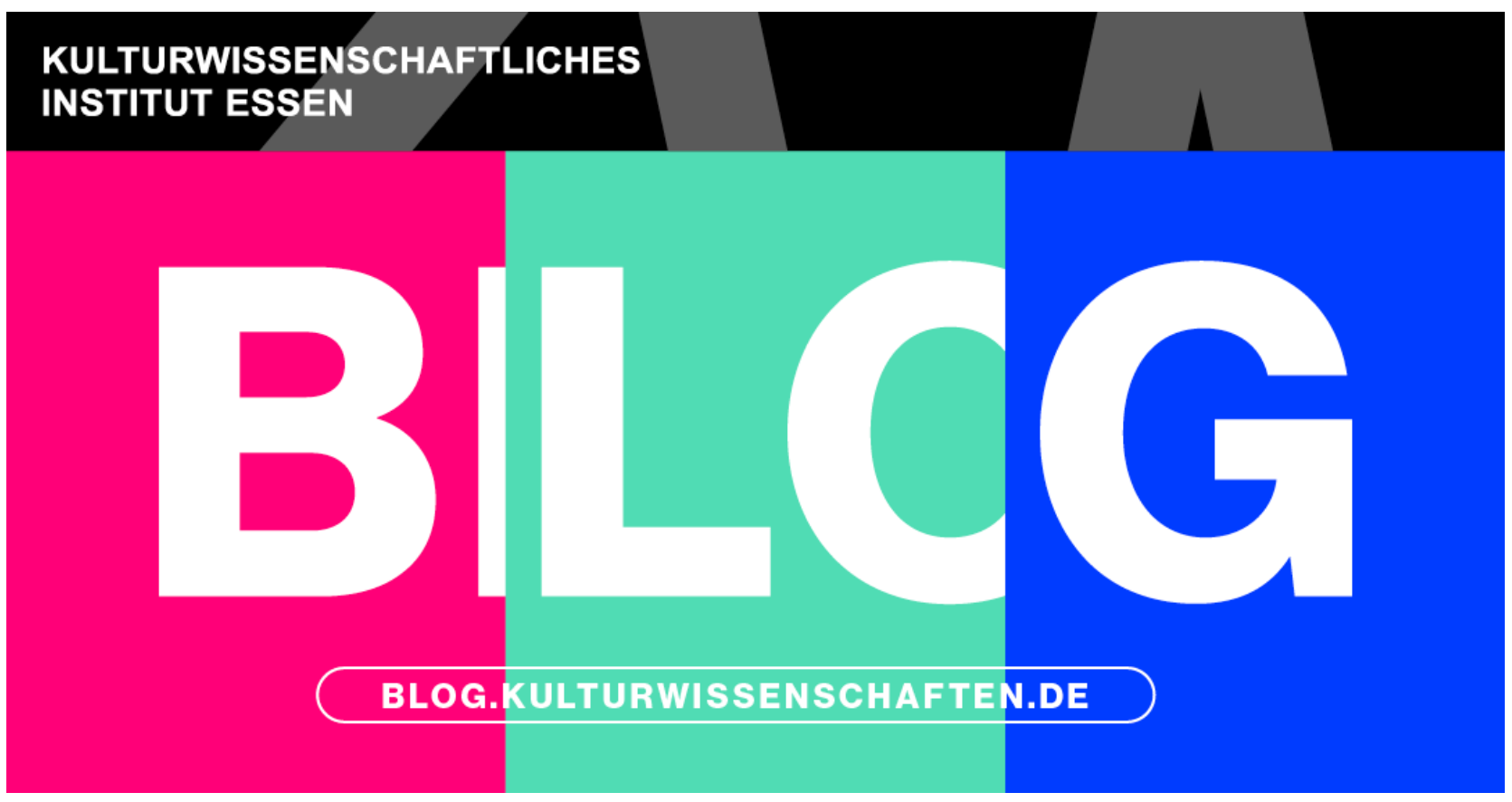

\title{
At the sports ground, with footnotes (II) Boys to British Men
}

Erschienen in: WORTATLAS

Von: Danilo Scholz

In contrast to Turnen, ${ }^{1}$ which was never really taken up outside Germany and which cemented a Sonderweg in the realm of athletics, English sports broke through nationstate borders and spread across the world in the nineteenth century. Perhaps no setting would prove so decisive for the historical development of modern sports as Great Britain's schools and universities, though two early enthusiasms, cricket and rowing, at first gave little hint of the global influence to come. Cricket, a favoured pastime of aristocratic gentleman, was the first game played on the grounds of Oxford and Cambridge; however, the expenses associated with crisp attire and elaborate kit ensured that the less well-bred did not disturb the cricket field's proverbial fair play. Rowing, eagerly practiced on the Cam and the Thames by the 1840s, was almost demotic by comparison - the cost of boats and oars was shouldered by clubs, keeping individual contributions manageable for middle-class students - but it nonetheless failed to win mass appeal. ${ }^{2}$

The sport that shattered class boundaries to become, in the words of historian Eric Hobsbawm, the global "lingua franca" of athletics, can paradoxically trace its modern roots back to another exclusive pursuit of England's elite. ${ }^{3}$ Public schools like Eton and Harrow were a refuge for scions of the aristocracy, landed gentry, and the growing uppermiddle class. But it would be misguided to imagine these institutions as educational Arcadias: pupils regularly rose up against fusty curricula, overbearing schoolmasters, and harsh discipline. In some cases, militias had to be dispatched to quell student unrest. 
Teachers frowned upon the delight their charges took in rowdy ball games, anarchic and savage affairs devoid of rules and decidedly unbecoming for reputable young men of pedigree. Samuel Butler, the headmaster of Shrewsbury public school, averred that what was already called football was "more fit for farm boys and labourers than for young gentlemen". 4

Such supercilious disdain gradually gave way to an educational philosophy that emphasised physical resilience, Protestant self-control, and an unwavering faith in England's maritime mission. This "muscular Christianity" prized outdoor activities as boot camps for a new imperial ruling class. Provided that a body of regulations pare back the worst excesses of brutality and maintain a certain degree of order, football, a team sport extolling cooperation and competition in equal measure, could be seen to encourage the very same process of character building. In the words of Charles Kingsley, an eloquent advocate, through "sport boys acquire virtues which no books can give them: not merely daring and endurance, but better still, temper, self-restraint, fairness, honour, unenvious appropriation of another's success and all that 'give and take' of life which stand a man in good stead when he goes forth into the world and without which, indeed, his success is always maimed and partial." 5 Thomas Hughes, an old boy from Rugby, embroidered the athletic precepts of this ethos with an adventure yarn in his 1857 novel Tom Brown's Schooldays, based on his own experience at the prestigious public school. The exhilarating, exclusively masculine pursuit of football soon became a national craze. The fact that vigorous sporting activity was thought to keep a lid on the bodily vices most despised by Victorian ideologues - masturbation, effeminacy and homosexuality likewise favoured football's newfound fashionability.

Official sanction from on high authorised the construction of designated sports grounds. The surface taken up by the playing fields at public schools expanded massively over the second half of the century: by 1900 they measured 146 acres at Harrow, which in 1845 boasted only eight acres. And it was only natural that public-school boys take their athletic preoccupations with them when they "went up" to Oxford or Cambridge. Mark Pattison, rector of Lincoln College Oxford, was moved to denounce "the mastery which the athletic furore has established over all minds in this place." ${ }^{6}$ But there was no holding back the tide. If need be, in the absence of a proper football pitch any piece of green could be swiftly converted. As early as 1612, Cambridge Corporation had acquired twenty-five acres of land a short walking distance from the centre of town. Two centuries later, enclosure acts had privatised and partitioned a sizeable portion, but part of the area - Parker's Piece, as locals referred to it - remained common land, a dedicated place for sports and leisure. Throughout the nineteenth century, it was a multi-use facility in the best sense of term. Public-school footballers "played their part in inventing the modern game" there, writes the historian Robert Colls, "schoolgirls" did "their exercises, cricketers batted and bowled, locals strolled, and fatstock grazed while trees were planted and new paths laid". 7

Notwithstanding such scenes of idyllic frolicking, football experienced its fair share of growing pains. Filial piety on the part of alumni towards their alma mater bred a stubborn attachment to the idiosyncratic rules of the public schools, a source of endless quarrelling 
that spilt over into the country's two oldest universities. Harrow, Eton, Charterhouse and Winchester preferred a kicking and dribbling game, whereas Rugby and Marlborough allowed for more handling of the ball. Recriminations were common, and for a time the prospect of settling on the rules of the "simplest game" appeared dim. In 1863, a missive from Eton appeared in the Times letter section proposing "the framing of set rules for the game of football to be played everywhere." 8 Rival public schools ignored the call, but other clubs and schools convened in autumn to lay the foundation for the Football Association (FA). Still, it took a number of meetings and much heated discussion to arrive at a compromise. Those gathered eventually took their cue from the rules set down by Cambridge University, vaunted for their simplicity. In addition, in a crucial departure from the game played at Rugby School, no player was allowed to carry the ball in his hands. The framework continued to evolve over the coming years, until football in its modern form - "association football," as contemporaries termed it, which Victorian slang abbreviated to "soccer" - won a sufficiently commanding consensus, and even then, offside rules required further tinkering.

Popularised by the sons of England's ruling class, the sport was rapidly wrested from their grasp. While Oxford won the FA Challenge Cup in 1873, its rival Cambridge never carried off a victory, and the last time the Old Etonians triumphed was in 1882 - to be beaten the following year by a working-class side from the industrial northern town of Blackburn. It was a veritable "Waterloo" for public-school self-confidence, the Manchester Guardian wrote, and heralded the emergence of football as the people's game. For the upper crust, admitting defeat to social inferiors, even if only in a game, was a bitter pill to swallow. The 1883 upset accordingly elicited a torrent of class resentment, with one contemporary complaining that "employment of the scum of Scottish villages has tended, in no small degree, to brutalise the game". 9

Clubs formed together into a league and were run as businesses, in a clear break with aristocratic amateurism. For a while, the Corinthians - an amateur club assembling the most gifted public-school and Oxbridge players - cultivated a high-minded, almost haughty style of attacking football. They refused to enter the FA cup, but on a good day they easily beat professional teams including reigning champions in friendlies.

Throughout the 1880s and 1890s, Corinthians constituted the backbone of the English national team. But this was a last hurrah. In the twentieth century, English students continued to play football at university, but this was now an undergraduate hobby, enlivened by rivalries to be sure but no longer a bellwether of football's evolution and thus of limited public interest. Meanwhile, in the former colonies across the Atlantic, college sports were growing into an American national obsession and eventually one of the most lucrative media spectacles in the world.

\section{References}


1. For the first part of this series see Scholz, Danilo: At the sports ground, with footnotes (I): Stretching for the Fatherland, in: KWI-BLOG, [https://blog.kulturwissenschaften.de/at-the-sports-ground-with-footnotes-i/], 15.11.2021, DOI: https://doi.org/10.37189/kwi-blog/20211115-0830

2. Mark C. Curthoys and Stuart Jones, "Oxford Athleticism, 1850-1914", History of Education 24, no. 4, 1995, p. 305-317, here p. 306. https://doi.org/10.1080/0046760950240403.

3. Eric Hobsbawm, Worlds of Labour, London: Weidenfeld \& Nicolson, 1984, p. 206.

4. Quoted in Richard Holt, Sport and the British. A Modern History, Oxford: Clarendon Press, 1989, p. 75.

5. Ibid., p. 93.

6. Mark Pattison, Suggestions on Academical Organisation, Edinburgh: Edmonston and Douglas, 1868, p. 316.

7. Robert Colls, This Sporting Life: Sport and Liberty in England, 1760-1960, Oxford: University Press, 2020, p. 145. https://doi.org/10.1093/oso/9780198208334.001.0001.

8. "Etonensis", The Times, 5 October 1863.

9. Steven Tischler, Footballers and Businessmen. The Origins of Professional. Soccer in England, New York: Holmes and Meier, 1981, p. 44.

SUGGESTED CITATION: Scholz, Danilo: At the sports ground, with footnotes (II): Boys to British Men, in: KWI-BLOG, [https://blog.kulturwissenschaften.de/at-the-sportsground-with-footnotes-ii/], 06.12.2021

DOI: https://doi.org/10.37189/kwi-blog/20211206-0830 


\section{DuEPublico}

This text is made available via DuEPublico, the institutional repository of the University of Duisburg-Essen. This version may eventually differ from another version distributed by a commercial publisher.

DOI: $\quad 10.37189 / \mathrm{kwi}-\mathrm{blog} / 20211206-0830$

URN: urn:nbn:de:hbz:464-20211206-101253-0 